ARTICLE

\title{
Organic hydrogen peroxide-driven low charge potentials for high-performance lithium-oxygen batteries with carbon cathodes
}

Shichao Wu ${ }^{1,2}$, Yu Qiao ${ }^{1,2}$, Sixie Yang ${ }^{3}$, Masayoshi Ishida ${ }^{2}$, Ping $\mathrm{He}^{3}$ \& Haoshen Zhou ${ }^{1,2,3}$

Reducing the high charge potential is a crucial concern in advancing the performance of lithium-oxygen batteries. Here, for water-containing lithium-oxygen batteries with lithium hydroxide products, we find that a hydrogen peroxide aqueous solution added in the electrolyte can effectively promote the decomposition of lithium hydroxide compounds at the ultralow charge potential on a catalyst-free Ketjen Black-based cathode. Furthermore, for non-aqueous lithium-oxygen batteries with lithium peroxide products, we introduce a urea hydrogen peroxide, chelating hydrogen peroxide without any water in the organic, as an electrolyte additive in lithium-oxygen batteries with a lithium metal anode and succeed in the realization of the low charge potential of $\sim 3.26 \mathrm{~V}$, which is among the best levels reported. In addition, the undesired water generally accompanying hydrogen peroxide solutions is circumvented to protect the lithium metal anode and ensure good battery cycling stability. Our results should provide illuminating insights into approaches to enhancing lithium-oxygen batteries.

\footnotetext{
${ }^{1}$ Energy Technology Research Institute, National Institute of Advanced Industrial Science and Technology (AIST), 1-1-1, Umezono, Tsukuba 305-8568, Japan. ${ }^{2}$ Graduate School of System and Information Engineering, University of Tsukuba, 1-1-1, Tennoudai, Tsukuba 305-8573, Japan. ${ }^{3}$ Center of Energy Storage Materials and Technology, College of Engineering and Applied Sciences, National Laboratory of Solid State Microstructures, Collaborative Innovation Center of Advanced Microstructures, Nanjing University, Nanjing 210093, China. Correspondence and requests for materials should be addressed to H.Z.

(email: hs.zhou@aist.go.jp).
} 
$\mathrm{R}$ echargeable Li-air batteries with the high energy density of $\sim 3,500 \mathrm{Wh} \mathrm{kg}^{-1}$ demonstrate great promise for building capacious energy storage devices and developing electric vehicles with long driving range ${ }^{1}$. A typical Li-air battery is composed of a Li metal anode, a separator, an electrolyte and an air cathode ${ }^{2}$. The general net electrochemical reactions of non-aqueous $\mathrm{Li}-\mathrm{O}_{2}$ batteries during discharge and charge are based on the formation and oxidative decomposition of lithium peroxide $\left(2 \mathrm{Li}+\mathrm{O}_{2} \rightleftarrows \mathrm{Li}_{2} \mathrm{O}_{2}, E^{0}=2.96 \mathrm{~V} \text { versus } \mathrm{Li} / \mathrm{Li}^{+}\right)^{3-5}$. The insulating nature of $\mathrm{Li}_{2} \mathrm{O}_{2}$ depositing on the surface of the air cathode may result in sudden battery death or limited discharge capacity during discharge $e^{6-9}$. Upon charge, the potential will be too high to decompose $\mathrm{Li}_{2} \mathrm{O}_{2}(>4.2 \mathrm{~V})^{10}$. This may trigger the severe oxidative deterioration of the electrolyte and shorten the cycle life of the battery ${ }^{11,12}$. Such problems have blocked the realization of practical Li-air batteries. Carbon-based materials have been considered to be optimal selections for air cathodes, because their superior conductivity can buffer the poor electron conductivity of $\mathrm{Li}_{2} \mathrm{O}_{2}$ and thereby improve the discharge-charge performance ${ }^{13,14}$. They also show other advantages such as low cost and high specific area and light weight, which ensure the high specific capacity and energy density of Li- $\mathrm{O}_{2}$ batteries ${ }^{15}$. However, their poor catalysis ability towards the oxygen evolution reaction restrains the charge potential from realizing low values ${ }^{14}$. Substantial efforts have been devoted to lowering the charge potential ${ }^{16-21}$. Noble metals and oxides $\left(\mathrm{Pt}, \mathrm{Au}, \mathrm{Pd}, \mathrm{Ru}\right.$ and $\mathrm{RuO}_{2}$ and so on $)^{22-27}$ and transition metals and compounds $\left(\mathrm{MnO}_{2}\right.$, TiC, $\mathrm{Ti}_{4} \mathrm{O}_{7}, \mathrm{Cu}_{2} \mathrm{O}, \mathrm{FeOOH}, \mathrm{NiOOH}, \mathrm{Ni}_{2} \mathrm{CoO}_{4}$ and so on) have been tentatively introduced to construct carbon-based composite cathodes ${ }^{28-30}$. In this way, charge potentials of $\sim 3.5 \mathrm{~V}$ can be anticipated, but it is difficult to break through this limit. Also of note, the employment of inappropriate catalysts that strongly bind $\mathrm{O}_{2}$ or the discharge intermediate $\mathrm{LiO}_{2}$ may result in the undesired shift from $\mathrm{Li}_{2} \mathrm{O}_{2}$ to $\mathrm{Li}_{2} \mathrm{O}$ as discharge products and further lead to the poor reversibility of the Li- $\mathrm{O}_{2}$ battery ${ }^{31,32}$.

Recently, Li et al. ${ }^{33}$ in our group demonstrated a novel route to achieve the ultralow charge potential of $\sim 3.2 \mathrm{~V}$ in a dimethyl sulfoxide-based electrolyte containing 100 p.p.m. of $\mathrm{H}_{2} \mathrm{O}$ by constructing a composite cathode $\left(\mathrm{MnO}_{2}\right.$ and $\mathrm{Ru}$ particles supported on Super P carbon). The primary electrochemical reactions (the formation of $\mathrm{Li}_{2} \mathrm{O}_{2}$ ) during discharge were converted to the formation of lithium hydroxide $(\mathrm{LiOH})$ via the catalysis effect of $\mathrm{MnO}_{2}$ in the cathode towards the reactions between $\mathrm{Li}_{2} \mathrm{O}_{2}$ and $\mathrm{H}_{2} \mathrm{O}$. The discharge process was proposed to involve a $2 \mathrm{e}^{-}$electrochemical reaction and a following chemical reaction. During charge, $\mathrm{Ru}$ in the cathode decomposes the $\mathrm{LiOH}$ at the low charge potential. Following this idea, in a tetraglyme (G4)-based electrolyte, 4,600 p.p.m. of $\mathrm{H}_{2} \mathrm{O}$ was introduced to reduce the charge potential to $\sim 3.3 \mathrm{~V}^{34}$ and, by integrating a hydrophobic ionic liquid-based electrolytes, Wu et al. ${ }^{35}$ realized a synergistic system for $\mathrm{Li}^{-\mathrm{O}_{2}}$ batteries in a humid atmosphere (relative humidity of $51 \%$ ) and a charge potential of $\sim 3.34 \mathrm{~V}$ was attained. Although the transformed net electrochemical reactions based on the reversible formation and decomposition of $\mathrm{LiOH}$ compounds efficiently improve the charge ability and cycling performance, the introduction of $\mathrm{MnO}_{2}$ and $\mathrm{Ru}$ or $\mathrm{RuO}_{2}$, with their heavy molecular weight and high cost, such as the abovementioned carbon-based composite cathodes, is inevitably subject to significantly decreased energy density and increased cost. Moreover, the overly strong catalytic activity of these additional catalysts may lead to parasitic reactions of the electrolyte. In the cases with carbon cathodes containing no catalysts, the charge potentials have been very high, generally above $4.2 \mathrm{~V}$, although $\mathrm{H}_{2} \mathrm{O}$ was reported to largely enhance the discharge capacity $7,36,37$. Another work by Liu et al..$^{38}$, also based on the assumed LiOH-related discharge-charge mechanism, reported a charge potential of $\sim 3.1 \mathrm{~V}$ on an reduced graphene oxide ( $\mathrm{rGO}$ )-based cathode in a dimethyl ether-based electrolyte in the presence of $\mathrm{LiI}$ and $\mathrm{H}_{2} \mathrm{O}$. However, these features were not observed for $\mathrm{Li}-\mathrm{O}_{2}$ batteries with common carbon material-based cathodes such as Super P carbon. Furthermore, some discussion challenged the detailed function of LiI and the reversibility of the $\mathrm{Li}-\mathrm{O}_{2}$ battery with $\mathrm{LiOH}$ as the discharge product and suggested that the uncertain mechanism should be further explored ${ }^{39-42}$.

In this work, for an $\mathrm{H}_{2} \mathrm{O}$-containing $\mathrm{Li}^{-} \mathrm{O}_{2}$ battery with $\mathrm{LiOH}$ products, we reveal the critical role of an $\mathrm{H}_{2} \mathrm{O}_{2}$ aqueous solution added into the electrolyte in assisting the decomposition of $\mathrm{LiOH}$ compounds at the ultralow charge potential when using a common Ketjen Black carbon (KB)-based cathode. Most importantly, for non-aqueous $\mathrm{Li}-\mathrm{O}_{2}$ batteries with $\mathrm{Li}_{2} \mathrm{O}_{2}$ products, a novel electrolyte additive urea hydrogen peroxide that traps $\mathrm{H}_{2} \mathrm{O}_{2}$ in the $\mathrm{H}_{2} \mathrm{O}$-free organic is, to the best of our knowledge, first introduced to reduce the charge potential to as low as $\sim 3.26 \mathrm{~V}$ and simultaneously avoid $\mathrm{Li}$ metal anode corrosion by $\mathrm{H}_{2} \mathrm{O}$.

\section{Results}

Low charge potential for decomposing $\mathrm{LiOH}$ compounds. As $\mathrm{H}_{2} \mathrm{O}_{2}$ generally exists in aqueous solution (30 wt\%), to study the charge behaviour for decomposing $\mathrm{LiOH}$ compounds with or without the presence of $\mathrm{H}_{2} \mathrm{O}_{2}$ aqueous solution in the electrolyte, a Li metal anode-protected pouch cell is fabricated to prevent side reactions between the $\mathrm{Li}$ metal anode and $\mathrm{H}_{2} \mathrm{O}$ in the electrolyte $^{43}$. On the anode side, the $\mathrm{Li}$ metal is protected by utilizing a $\mathrm{Li}$ ion-conducting glass-ceramic film (LiSICON, $\mathrm{Li}_{2} \mathrm{O}-\mathrm{Al}_{2} \mathrm{O}_{3}-\mathrm{SiO}_{2}-\mathrm{P}_{2} \mathrm{O}_{5}-\mathrm{TiO}_{2}-\mathrm{GeO}_{2}$, Ohara Corporation, Japan), only allowing the transport of $\mathrm{Li}^{+}$and preventing the penetration of other ions. On the cathode side, a KB-based cathode and a glass fibre infiltrating electrolyte are constructed. Figure 1a presents the charge profiles for decomposing solid $\mathrm{LiOH}$ compounds on the KB-based cathode in the electrolytes with and without $\mathrm{H}_{2} \mathrm{O}_{2}$ solution. The $\mathrm{KB}$-based cathodes in situ loaded with solid $\mathrm{LiOH}$ compounds were obtained by first discharging $\mathrm{Li}-\mathrm{O}_{2}$ pouch cells in the dry electrolyte to $1.50 \mathrm{mAh}$ (corresponding to $\sim 4,000 \mathrm{mAh} \mathrm{g}^{-1} \mathrm{~KB}$ and $3.5 \mathrm{mAh} \mathrm{cm}^{-2}$, Fig. 1a,i), with $\mathrm{Li}_{2} \mathrm{O}_{2}$ as the product being evidenced by the $\mathrm{X}$-ray diffraction (XRD) pattern in Fig. 1c. Then, the discharged cathodes were extracted in an Ar glove box and left in an Ar atmosphere with a relative humidity of $75 \%$ for 7 days. The XRD pattern in Fig. 1d confirms that all the $\mathrm{Li}_{2} \mathrm{O}_{2}$ on the discharged cathode was converted to a mixture of $\mathrm{LiOH}$ and $\mathrm{LiOH} \cdot \mathrm{H}_{2} \mathrm{O}$. New Li- $\mathrm{O}_{2}$ pouch cells (Fig. 1a,ii) were assembled with these cathodes and $\mathrm{H}_{2} \mathrm{O}_{2}$-containing/free electrolytes to investigate the effect of $\mathrm{H}_{2} \mathrm{O}_{2}$ on the charge performance. In the $\mathrm{G} 4-\mathrm{H}_{2} \mathrm{O}$ electrolyte, the charge potential increased rapidly to a plateau at $\sim 4.16 \mathrm{~V}$, corresponding to the overpotential of $1.20 \mathrm{~V}$. This high value indicates the difficulty of decomposing $\mathrm{LiOH}$ compounds at the KB-based cathode without an efficient catalyst. At the end of the charge process (Fig. 1a,iii), the charge capacity is only $\sim 0.6 \mathrm{mAh}$, much lower than the discharged capacity $(\sim 1.50 \mathrm{mAh})$. The XRD pattern of the recharged cathode in Fig. 1e,iii illustrates that there are undecomposed $\mathrm{LiOH}$ compounds. We rationalize these observations by the poor catalytic activity of $\mathrm{KB}$ and the weakening contacts between $\mathrm{KB}$ particles and $\mathrm{LiOH}$ compound particles during the charging process ${ }^{33}$. In contrast, when $\mathrm{H}_{2} \mathrm{O}_{2}$ aqueous solution is introduced into the electrolyte, the charge plateau is greatly decreased to $\sim 3.50 \mathrm{~V}$ and the charge capacity is increased to above $1.40 \mathrm{mAh}$. It should be noted that $3.50 \mathrm{~V}$ is quite low, considering the large electrochemical impedance of the employed LiSICON film. The low charge overpotential of $\sim 0.54 \mathrm{~V}$ and the high recharge 

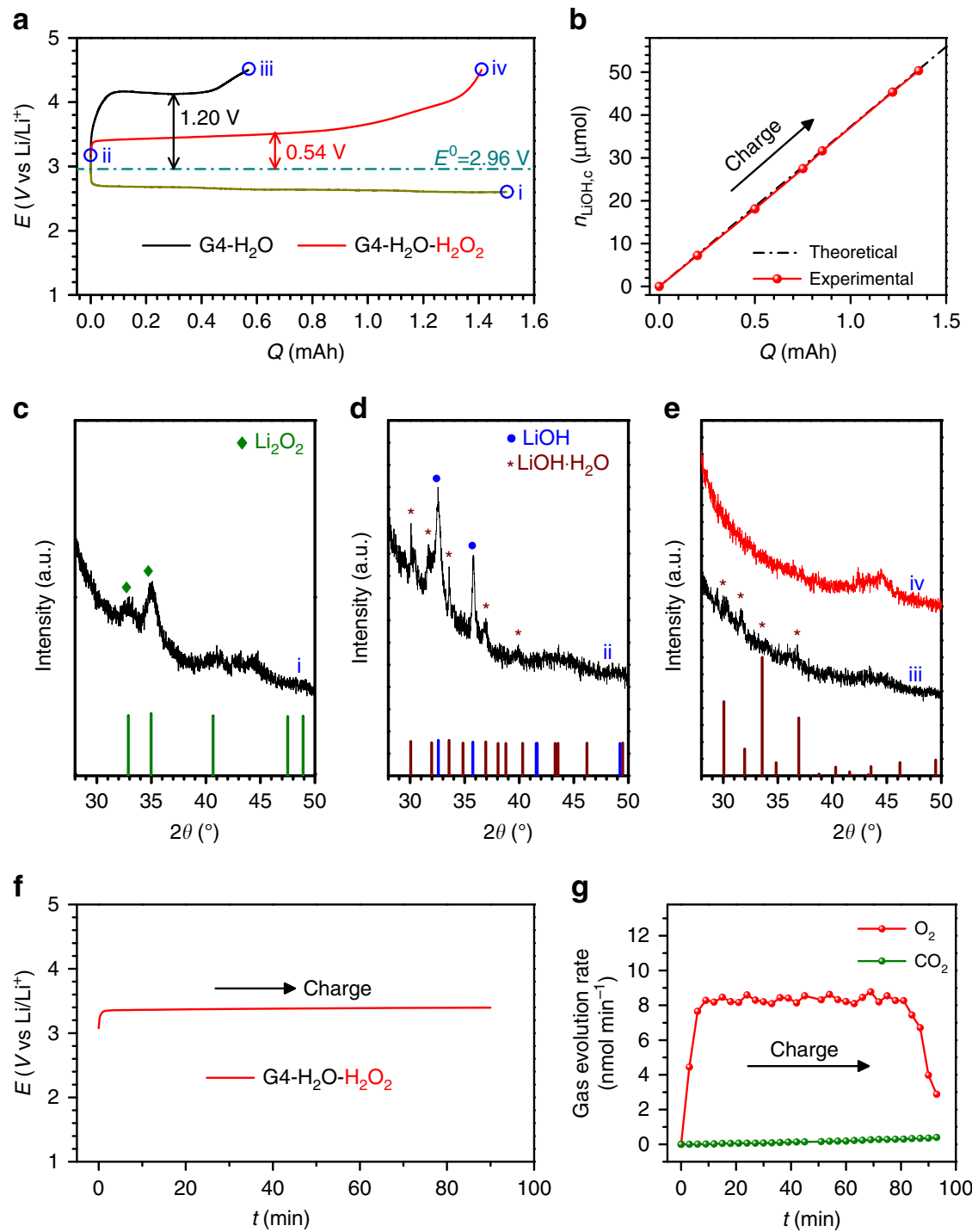

Figure 1 | The reduced charge potentials for decomposing LiOH compounds formed in situ. (a) The discharge and charge profiles at $100 \mathrm{mAg}-1 \mathrm{~KB}$. During charging, solid $\mathrm{LiOH}$ compounds can be oxidatively decomposed at a low potential of $3.50 \mathrm{~V}$ (corresponding to the overpotential of $0.54 \mathrm{~V}$ ) in the presence of $\mathrm{H}_{2} \mathrm{O}_{2}$ solution in the electrolyte. This is much lower than the value $\left(1.2 \mathrm{OV}\right.$ ) without $\mathrm{H}_{2} \mathrm{O}_{2}$. (b) The quantity of LiOH compounds consumed, $n_{\mathrm{LiOH}, c,}$ during charge determined by titration. (c-e) XRD patterns of cathodes corresponding to the different states (i, ii, iii and iv) in $\mathbf{a}$. The $\mathrm{Li}-\mathrm{O}_{2}$ pouch cell is first discharged to $1.5 \mathrm{mAh}$ (corresponding to $\sim 4,000 \mathrm{mAh} \mathrm{g}^{-1} \mathrm{~KB}_{\mathrm{K}}$ and $3.5 \mathrm{mAh} \mathrm{cm}^{-2}$ ) in the dry electrolyte to produce $\mathrm{Li}_{2} \mathrm{O}_{2}$ at the cathode (c). The $\mathrm{Li}_{2} \mathrm{O}_{2}$ is converted to a mixture of $\mathrm{LiOH}$ and $\mathrm{LiOH} \cdot \mathrm{H}_{2} \mathrm{O}$ (d) by keeping the cathode (i) in an Ar atmosphere with a relative humidity of $75 \%$ for 7 days. After charging, the $\mathrm{LiOH}$ and $\mathrm{LiOH} \cdot \mathrm{H}_{2} \mathrm{O}$ are reversibly oxidized at low charge potential in the presence of $\mathrm{H}_{2} \mathrm{O}_{2}$ in the electrolyte, evidenced by the disappearance of their diffraction peaks in e,iv, whereas $\mathrm{LiOH} \cdot \mathrm{H}_{2} \mathrm{O}$ remains undecomposed in the absence of $\mathrm{H}_{2} \mathrm{O}_{2}$ in the electrolyte (e,iii).

(f) Charge profiles of $\mathrm{Li}_{2} \mathrm{O}_{2}$ pouch cell with in situ formed solid $\mathrm{LiOH} / \mathrm{KB}$ cathode and $\mathrm{G} 4-\mathrm{H}_{2} \mathrm{O}-\mathrm{H}_{2} \mathrm{O}_{2}$ electrolyte during the in situ DEMS measurement. (g) Corresponding $\mathrm{O}_{2}$ and $\mathrm{CO}_{2}$ evolution rates during charge. Current density: $100 \mathrm{mAg}^{-1}{ }_{\mathrm{KB}}$. A LiSICON film preventing $\mathrm{H}_{2} \mathrm{O}$ penetration was employed to fabricate the $\mathrm{Li}_{-} \mathrm{O}_{2}$ pouch cells.

Coulombic efficiency of above $93 \%$ indicate the exceptional benefit of $\mathrm{H}_{2} \mathrm{O}_{2}$ in the electrolyte for decomposing $\mathrm{LiOH}$ compounds. The disappearance of $\mathrm{LiOH}$ compound peaks after recharge (Fig. 1e,iv) confirms their full decomposition and good charge reversibility. After charge, the electrolyte exhibits no obvious decomposition and no formation of soluble species, as evidenced by Fourier transform infrared (FTIR) spectra (Supplementary Fig. 1).

To quantitatively examine the charge process corresponding to the $\mathrm{LiOH}$ oxidation in the $\mathrm{H}_{2} \mathrm{O}_{2}$-containing electrolyte, we conducted a titration experiment to determine the consumed amount of $\mathrm{LiOH}$ at various charge states. The amount of these $\mathrm{LiOH}$ compounds $\left(n_{\mathrm{LiOHii}}\right)$ was quantified by titration following the method of McCloskey et al. ${ }^{44}$ When the newly assembled cells were charged to certain capacities $(0.2,0.5,0.75,0.85,1.22$ or $1.356 \mathrm{mAh})$, the residual amount of $\mathrm{LiOH}$ compounds was titrated and the consumed amount of $\mathrm{LiOH}$ compounds could be obtained by subtracting the $\mathrm{LiOH}$ compounds at each point from $n_{\mathrm{LiOHii}}$. As shown in Fig. $1 \mathrm{~b}$, at each point during the charge process, the calculated amount of $\mathrm{LiOH}$ compounds consumed was almost equal to the theoretical value and the relationship of the consumed amount and the charge capacity is linearly dependent. In situ differential quantitative mass spectrometry (DEMS) was performed to examine whether $\mathrm{O}_{2}$ could be generated from $\mathrm{LiOH}$ decomposition at the low charge potential in the presence of $\mathrm{H}_{2} \mathrm{O}_{2}$. As shown in Fig. 1f,g, clear 
$\mathrm{O}_{2}$ evolution can be detected at $\sim 3.50 \mathrm{~V}$ during the charge process and there is no evolution of $\mathrm{CO}_{2}$. Accordingly, these quantitative results indicate that the oxidation of $\mathrm{LiOH}$ compounds dominates in the charge process.

We also examined the charge performance of commercial $\mathrm{LiOH}$-preloaded $\mathrm{KB}$-based cathodes in the $\mathrm{H}_{2} \mathrm{O}_{2}$-containing/free electrolytes. The results are shown in Fig. 2a and Supplementary Fig. 2. With the aid of $\mathrm{H}_{2} \mathrm{O}_{2}$ in the electrolyte, the preloaded $\mathrm{LiOH}$ in the KB-based cathode is much easier to fully decompose at a low charge potential $(\sim 3.61 \mathrm{~V}$, Fig. $2 \mathrm{a})$ than in the absence of $\mathrm{H}_{2} \mathrm{O}_{2}(>4.40 \mathrm{~V})$. In Fig. $2 \mathrm{~b}$, we present the charge profiles of $\mathrm{Li}-\mathrm{O}_{2}$ pouch cells with dissolved $\mathrm{LiOH}$ aqueous solution and dissolved $\mathrm{LiOH}-\mathrm{H}_{2} \mathrm{O}_{2}$ aqueous solution in the electrolytes. The presence of $\mathrm{H}_{2} \mathrm{O}_{2}$ allows a large reduction of charge overpotentials to $0.55 \mathrm{~V}$ from $1.50 \mathrm{~V}$ in the absence of $\mathrm{H}_{2} \mathrm{O}_{2}$. After charge at high potential in $\mathrm{G} 4-\mathrm{H}_{2} \mathrm{O}-\mathrm{LiOH}_{(1)}$ electrolyte, the $\mathrm{LiOH}$ peak at $\sim 3,680 \mathrm{~cm}^{-1}$ in FTIR spectra (Supplementary Fig. 3,iii) remains, indicating the uncomplete decomposition of liquid $\mathrm{LiOH}$ in the electrolyte. In contrast, the $\mathrm{LiOH}$ can be fully decomposed after charge at low potential in the $\mathrm{H}_{2} \mathrm{O}_{2}$-containing electrolyte, as evidenced by the peak having disappeared (Supplementary Fig. 3,iv). This phenomenon may provide some insights into the improvement of the aqueous $\mathrm{Li}^{-\mathrm{O}_{2}}$ battery by adding $\mathrm{H}_{2} \mathrm{O}_{2}$ into the aqueous electrolyte; further work will continue to explore this phenomenon. All of these results emphasize that the introduction of $\mathrm{H}_{2} \mathrm{O}_{2}$ in the electrolyte can greatly enhance the decomposition ability of either solid $\mathrm{LiOH}$ compounds at common carbon cathodes or liquid $\mathrm{LiOH}$ in the electrolyte at low potentials during the charge process.
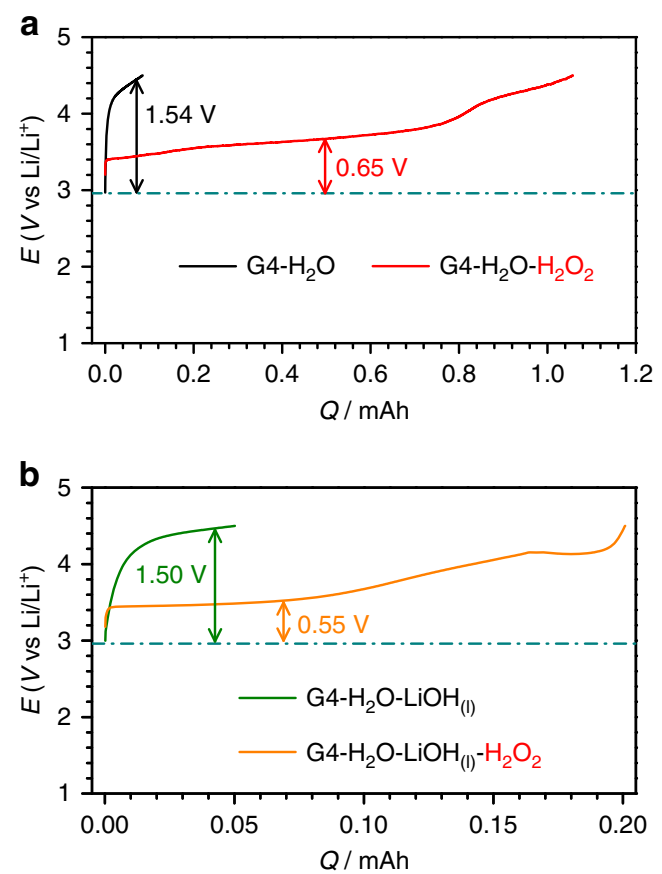

Figure 2 | The reduced charge potentials for decomposing preloaded LiOH. (a) Preloaded commercial $\mathrm{LiOH}$ on a KB-based cathode at $100 \mathrm{~mA} \mathrm{~g}^{-1} \mathrm{~KB}$ and (b) liquid $\mathrm{LiOH}$ in the $\mathrm{G} 4$-based electrolyte by the action of $\mathrm{H}_{2} \mathrm{O}_{2}$ (current density: $100 \mathrm{mAg}^{-1}{ }_{\mathrm{KB}}$ ). During charging, the preloaded $\mathrm{LiOH}$ can be decomposed at a low potential of $\sim 3.61 \mathrm{~V}$ (corresponding to the overpotential of $0.65 \mathrm{~V}$ ) in the presence of $\mathrm{H}_{2} \mathrm{O}_{2}$ solution in the electrolyte. This is much lower than the value $(1.54 \mathrm{~V})$ without $\mathrm{H}_{2} \mathrm{O}_{2}$. For the liquid $\mathrm{LiOH}$, the charge overpotential is reduced from $1.50 \mathrm{~V}$ in the absence of $\mathrm{H}_{2} \mathrm{O}_{2}$ to $0.55 \mathrm{~V}$ in the presence of $\mathrm{H}_{2} \mathrm{O}_{2}$ in the electrolyte. The battery configuration is that of the $\mathrm{Li}-\mathrm{O}_{2}$ pouch cell.
In view of the superiority of $\mathrm{H}_{2} \mathrm{O}_{2}$ in improving the charge performance in $\mathrm{Li}-\mathrm{O}_{2}$ batteries, the cycling stability is expected to be promoted. Supplementary Fig. 4 shows the discharge-charge profiles of $\mathrm{Li}-\mathrm{O}_{2}$ pouch cells with $\mathrm{H}_{2} \mathrm{O}_{2}$ aqueous solution in the electrolyte. Pure KB is used as the active material for the cathode and LiSICON film is used to protect the Li metal anode from corrosion by $\mathrm{H}_{2} \mathrm{O}$. The pouch cells were discharged and charged with a limited specific capacity of $1,000 \mathrm{mAhg}^{-1} \mathrm{~KB}$ at $100 \mathrm{mAg}^{-1}{ }_{\mathrm{KB}}$ and a voltage range of $2.00-4.50 \mathrm{~V}$. In the ten cycles, the discharge plateaus are at $\sim 2.70 \mathrm{~V}$ and remain nearly unchanged. For the charge profiles, the first plateau is at $\sim 3.45 \mathrm{~V}$ and the charge-specific capacity can reach $1,000 \mathrm{mAh} \mathrm{g}^{-1} \mathrm{~KB}_{\mathrm{K}}$ with a terminal charge potential of $<4.00 \mathrm{~V}$ at the end of charge process, indicating the strong charge ability and reversibility. In the initial five cycles, the low charge plateaus remain and the terminal charge potentials show no notable increase. Until the sixth cycle, the charge plateau increases to $\sim 3.65 \mathrm{~V}$ and the terminal potential reaches the limitation of $4.50 \mathrm{~V}$ in addition to the charge-specific capacity decreasing to $950 \mathrm{mAhg}^{-1} \mathrm{~KB}$. After ten cycles, the charge profile shows a large increment (to $\sim 4.00 \mathrm{~V}$ ) of the plateau and poor reversibility (charge capacity of only $800 \mathrm{mAhg}^{-1} \mathrm{~KB}$ ). Electrochemical impedance analysis was performed before and after the cycles to determine the cause of the fading cycling stability (Supplementary Fig. 5). The first arcs in the high-frequency region corresponding to the interphase impedance are almost constant before and after ten cycles. However, the second arc in the middle-frequency region corresponding to the charge transfer notably changes ${ }^{45,46}$. The large increase from $2.5 \mathrm{k} \Omega$ in the first cycle to $3.6 \mathrm{k} \Omega$ after the ten cycles is responsible for the difficulty of the $\mathrm{Li}^{+}$transfer through the LiSICON film and the resulting poor cycling performance. These results imply that adopting the LiSICON film to overcome the $\mathrm{H}_{2} \mathrm{O}$ addition accompanying the $\mathrm{H}_{2} \mathrm{O}_{2}$ aqueous solution in the $\mathrm{Li}-\mathrm{O}_{2}$ pouch cell is inadvisable in terms of realizing long cycle life and alternative strategies should be sought to exploit the merits of $\mathrm{H}_{2} \mathrm{O}_{2}$ for enhancing the performance of $\mathrm{Li}-\mathrm{O}_{2}$ batteries.

Organic $\mathrm{H}_{2} \mathrm{O}_{2}$ compound introduction. In the general battery configuration with a KB-based cathode/glass fibre separator infiltrating electrolyte/ $\mathrm{Li}$ metal anode structure, if the normal $\mathrm{H}_{2} \mathrm{O}_{2}$ aqueous solution is introduced in the electrolyte (Fig. 3a), the concomitant $\mathrm{H}_{2} \mathrm{O}$ will inevitably attack the $\mathrm{Li}$ metal anode, causing battery death and possible safety issues. As shown in Fig. 3d, even only 5,000 p.p.m. of $\mathrm{H}_{2} \mathrm{O}$ in the electrolyte can lead to serious corrosion of the $\mathrm{Li}$ metal anode after cycling. Large amounts of $\mathrm{LiOH}$ (determined by the XRD, Fig. 3c) cover the surface of the Li metal anode and cut off the $\mathrm{Li}^{+}$generation and transfer. This would probably result in the decreased dischargespecific capacity and battery failure within only a few cycles (Fig. 3b).

To exploit the merits of $\mathrm{H}_{2} \mathrm{O}_{2}$ for reducing the charge overpotential and extending cycle life, introducing $\mathrm{H}_{2} \mathrm{O}_{2}$ in the electrolyte while eliminating $\mathrm{H}_{2} \mathrm{O}$ contamination should be a quick fix. Herein, we pilot an organic $\mathrm{H}_{2} \mathrm{O}_{2}$ compound (urea hydrogen peroxide, $\mathrm{UH}_{2} \mathrm{O}_{2}$ ) as the electrolyte additive to lower the charge potential and more importantly, to prohibit $\mathrm{H}_{2} \mathrm{O}$-related side reactions (Fig. 4a). Urea has been reported to form deep eutectic electrolytes with LiTFSI, have pronounced effects on the transport and structural properties of LiTFSI and induce faster $\mathrm{Li}^{+}$diffusion and improved ion transport ${ }^{47}$. The ion conductivity of the $\mathrm{G} 4-\mathrm{UH}_{2} \mathrm{O}_{2}$ electrolyte is determined to $1.8 \times 10^{-3} \mathrm{~S} \mathrm{~cm}^{-1}$ through the Nyquist plot in Supplementary Fig. 6. This value is comparable to the levels of commercial electrolytes for $\mathrm{Li}$ ion batteries and indicates the high $\mathrm{Li}^{+}$ conductivity. In the electrolyte containing $\mathrm{UH}_{2} \mathrm{O}_{2}$, the rate 
a

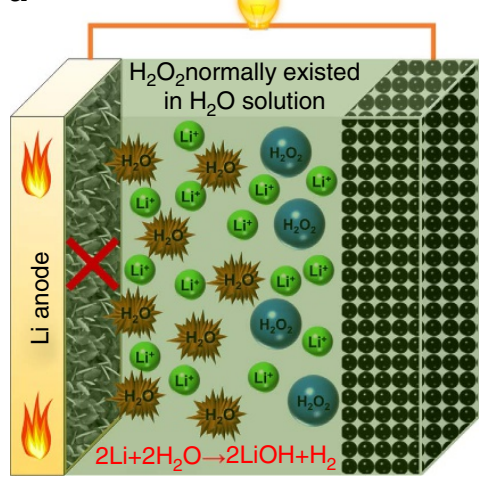

c

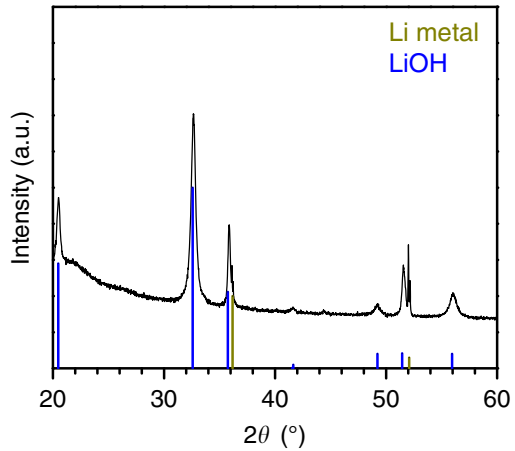

b

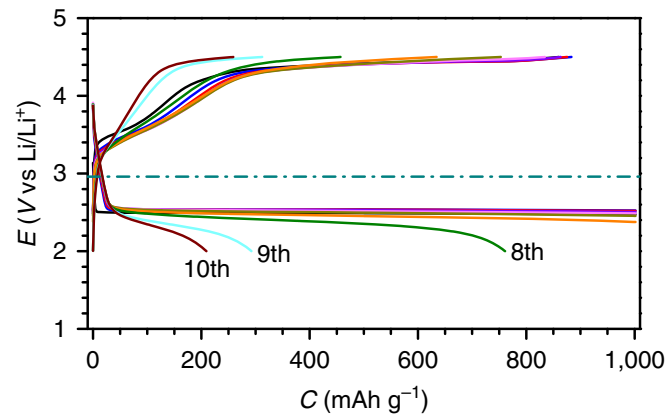

d

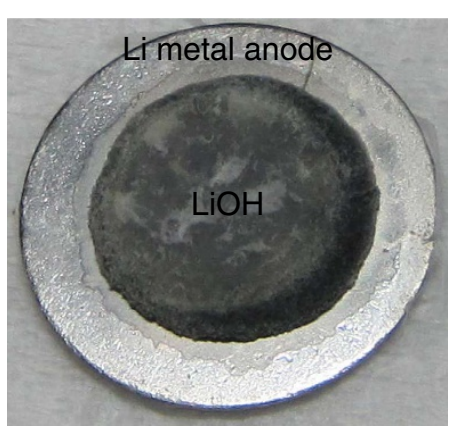

Figure 3 | $\mathrm{H}_{2} \mathrm{O}$-induced poor battery performance and corrosion of the Li metal anode. (a) Schematic illustrations of $\mathrm{Li}-\mathrm{O}_{2}$ cells with a general configuration (KB-based cathode/glass fibre separator infiltrating electrolyte/Li metal anode) in the $\mathrm{G} 4-\mathrm{H}_{2} \mathrm{O}-\mathrm{H}_{2} \mathrm{O}_{2}$ electrolyte. (b) Discharge-charge profiles of $\mathrm{Li}_{-} \mathrm{O}_{2}$ cells with 5,000 p.p.m. of $\mathrm{H}_{2} \mathrm{O}$ in the electrolyte (current density: $500 \mathrm{mAg}^{-1}{ }_{\mathrm{KB}}$ ). (c) The XRD pattern of the Li metal anode after cycling in the electrolyte containing 5,000 p.p.m. of $\mathrm{H}_{2} \mathrm{O}$. (d) A photo of a Li metal anode after cycling in the electrolyte containing 5,000 p.p.m. of $\mathrm{H}_{2} \mathrm{O}$. In the presence of $\mathrm{H}_{2} \mathrm{O}_{2}$ aqueous solution, the Li metal anode was significantly corroded, resulting in $\mathrm{LiOH}$ on the surface, and the battery performance faded rapidly.

performances of $\mathrm{Li}_{2} \mathrm{O}_{2}$ cells were evaluated at current densities of $100,250,500$ and $1,000 \mathrm{mAg}^{-1}{ }_{\mathrm{KB}}$; the results are given in Fig. $4 \mathrm{~b}$. At $100 \mathrm{mAg}^{-1}{ }_{\mathrm{KB}}$, the charge plateau is at $\sim 3.26 \mathrm{~V}$, corresponding to the much lower overpotential of $0.30 \mathrm{~V}$, which is among the lowest values reported. Even at the high current density of $1,000 \mathrm{~mA} \mathrm{~g}^{-1}{ }_{\mathrm{KB}}$, the charge plateau is only $\sim 3.44 \mathrm{~V}$, suggesting the excellent rate capability. With regard to the $\mathrm{Li}$ metal anode, no $\mathrm{LiOH}$ was detected on the surface of the Li metal anode after cycling, as expected (Fig. 4c). The silvery grey colour in the photo in Fig. $4 \mathrm{~d}$ confirms the Li metal anode to be intact, in sharp contrast with the almost damaged Li metal anode (photo in Fig. 3d). In addition, from the storage experiments (Supplementary Fig. 7), the steady open circuit voltage trends after a discharge process or one discharge-charge cycle indicate the solid stability of the $\mathrm{Li}-\mathrm{O}_{2}$ cells with the $\mathrm{G} 4-\mathrm{UH}_{2} \mathrm{O}_{2}$ electrolyte. The results verify that employing the organic $\mathrm{UH}_{2} \mathrm{O}_{2}$ as an electrolyte additive is an accessible way to ensure the attractive charge performance of the $\mathrm{Li}-\mathrm{O}_{2}$ cell and achieve high stability of the Li metal anode, along with maintaining reliable safety.

The discharge products on the cathode of the $\mathrm{Li}-\mathrm{O}_{2}$ cell in the G4- $\mathrm{UH}_{2} \mathrm{O}_{2}$ electrolyte were analysed by XRD and scanning electron microscopy (SEM). Figure 5a summarizes the XRD patterns of pristine, discharged and recharged cathodes. The discharge products are determined to be $\mathrm{Li}_{2} \mathrm{O}_{2}$. After recharge, the diffraction peaks of $\mathrm{Li}_{2} \mathrm{O}_{2}$ disappear, implying its full decomposition. The typical toroid morphology of $\mathrm{Li}_{2} \mathrm{O}_{2}$ after discharge can be directly observed from Fig. $5 \mathrm{c}$. After the cell is recharged, the particles are completely decomposed (Fig. 5d). This is in good agreement with the XRD results.
As the reactions during discharge and charge in the $\mathrm{Li}-\mathrm{O}_{2}$ cell are complex multiphase processes, it is necessary to confirm whether the low charge potential in the $\mathrm{Li}-\mathrm{O}_{2}$ cell with the G4- $\mathrm{UH}_{2} \mathrm{O}_{2}$ electrolyte resulted from the improved charge ability or the unexpected side reactions. Therefore, we conducted in situ DEMS measurement to monitor the $\mathrm{O}_{2}$ evolution during charge and titration experiments, to quantitatively analyse the $\mathrm{Li}_{2} \mathrm{O}_{2}$ formation and consumption during discharge and charge in the $\mathrm{Li}-\mathrm{O}_{2}$ cell with the $\mathrm{G} 4-\mathrm{UH}_{2} \mathrm{O}_{2}$ electrolyte. The corresponding data are provided in Fig. 6. After discharging the cell to 0.1, 0.2, $0.3,0.4$ or $0.5 \mathrm{mAh}$ at $0.05 \mathrm{~mA}$, the $\mathrm{Li}_{2} \mathrm{O}_{2}$ formation was quantified by a titration method (Fig. 6c). The yields of the formed $\mathrm{Li}_{2} \mathrm{O}_{2}$ (the amount of $\mathrm{Li}_{2} \mathrm{O}_{2}$ titrated divided by the amount of $\mathrm{Li}_{2} \mathrm{O}_{2}$ expected given the coulometry) held at $\sim 91 \%$. This value is similar to the yield reported by McCloskey et al. ${ }^{44}$ and indicates some slight side reactions, possibly corresponding to inevitable electrolyte decomposition. The value of $\mathrm{e}^{-} / \mathrm{Li}_{2} \mathrm{O}_{2}$ can be estimated to be 2.15 , close to the theoretical value of 2 . The gas evolution rates of $\mathrm{O}_{2}$ and $\mathrm{CO}_{2}$ upon charge are presented in Fig. 6b. $\mathrm{O}_{2}$ evolution was detected from the beginning and continued along the charge potential of $\sim 3.3 \mathrm{~V}$ during the whole charge process. No evolution of $\mathrm{CO}_{2}$ was detected. The amounts of $\mathrm{Li}_{2} \mathrm{O}_{2}$ consumed during charge were analysed by titration measurement (Fig. 6d). $\mathrm{Li}_{2} \mathrm{O}_{2}$ oxidation follows an $\sim 2.14 \mathrm{e}^{-} / \mathrm{Li}_{2} \mathrm{O}_{2}$ process during the whole charge process. This value approaches the ideal value of 2 and clearly demonstrates that the significant reduction of charge overpotential due to the $\mathrm{UH}_{2} \mathrm{O}_{2}$ additive in the electrolyte can prohibit the high charge potential-induced side reaction and that the introduction of $\mathrm{UH}_{2} \mathrm{O}_{2}$ can improve the charge performance. The DEMS and 


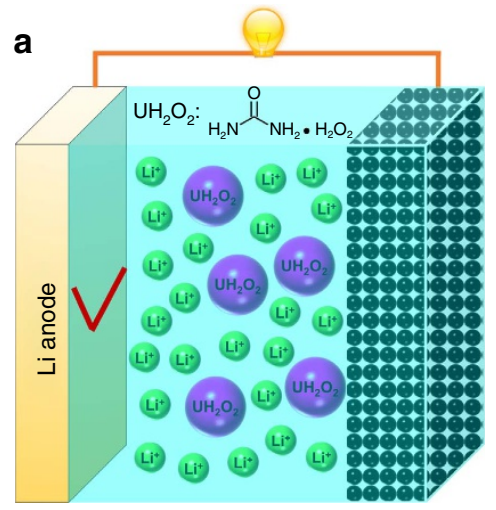

b
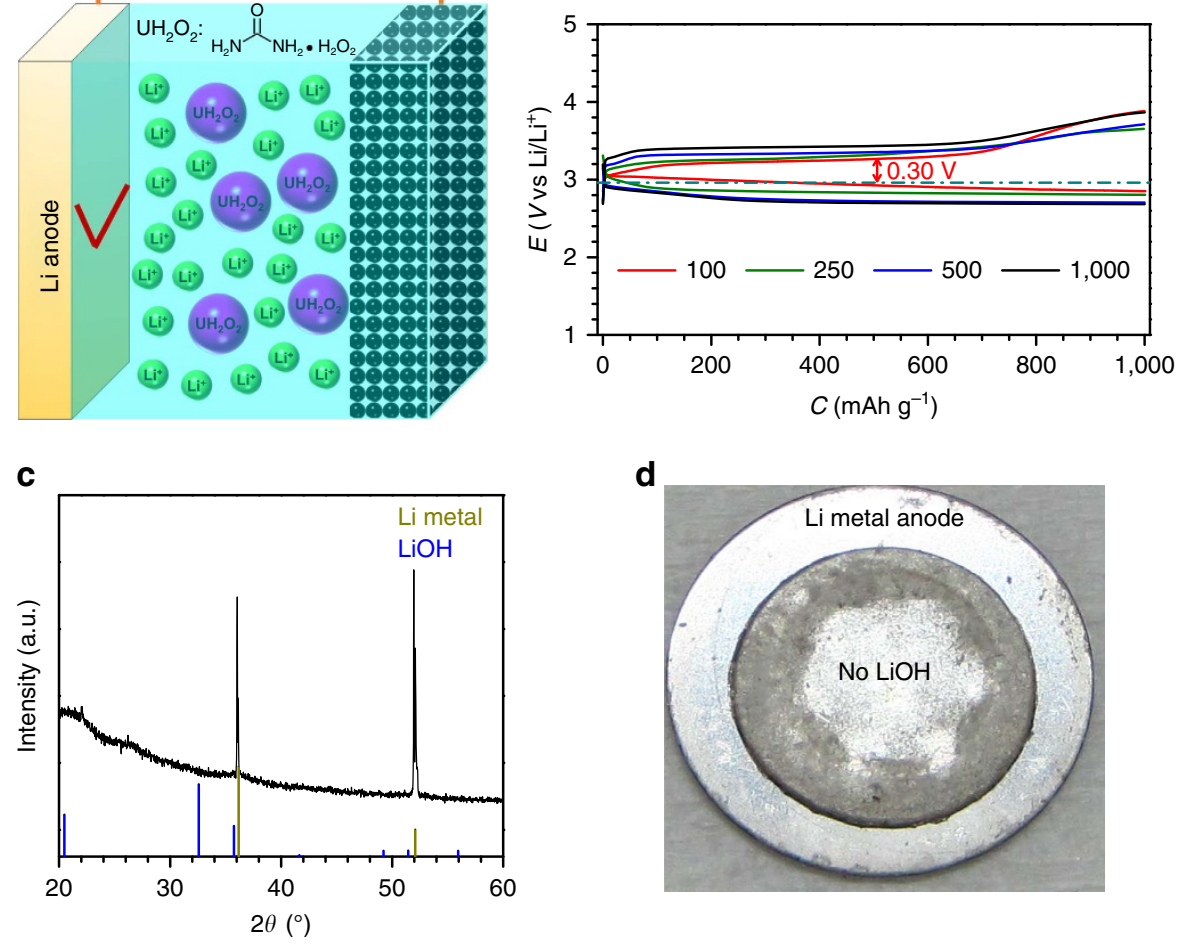

d

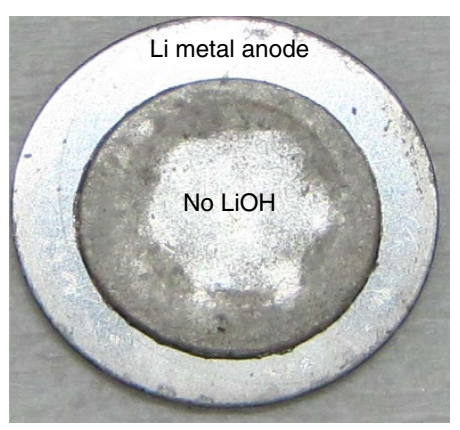

Figure 4 | Blocking of $\mathbf{H}_{\mathbf{2}} \mathbf{O}$-induced problems in the developed $\mathbf{G} 4-\mathbf{U H}_{\mathbf{2}} \mathbf{O}_{\mathbf{2}}$ electrolyte. (a) Schematic illustrations of $\mathrm{Li}-\mathrm{O}_{2}$ cells with a general configuration (KB-based cathode/glass fibre separator infiltrating electrolyte/Li metal anode) in the developed $\mathrm{G}_{4}-\mathrm{UH}_{2} \mathrm{O}_{2}$ electrolyte. (b) Rate performance of a Li- $\mathrm{O}_{2}$ coin cell in the $\mathrm{G} 4-\mathrm{UH}_{2} \mathrm{O}_{2}$ electrolyte. (c) The XRD pattern of the Li metal anode after cycling in the $\mathrm{G}_{4}-\mathrm{UH}_{2} \mathrm{O}_{2}$ electrolyte. (d) The photo of a Li metal anode after cycling in the $\mathrm{G} 4-\mathrm{UH}_{2} \mathrm{O}_{2}$ electrolyte. In the $\mathrm{G} 4-\mathrm{UH}_{2} \mathrm{O}_{2}$ electrolyte without $\mathrm{H}_{2} \mathrm{O}$, the $\mathrm{Li}$ metal anode remained undamaged. The $\mathrm{Li}_{-} \mathrm{O}_{2}$ coin cell achieves the ultralow charge potential of $3.26 \mathrm{~V}$ (overpotential of $0.30 \mathrm{~V}$ ) at $100 \mathrm{mAg}^{-1} \mathrm{~KB}$ with an excellent rate capability.
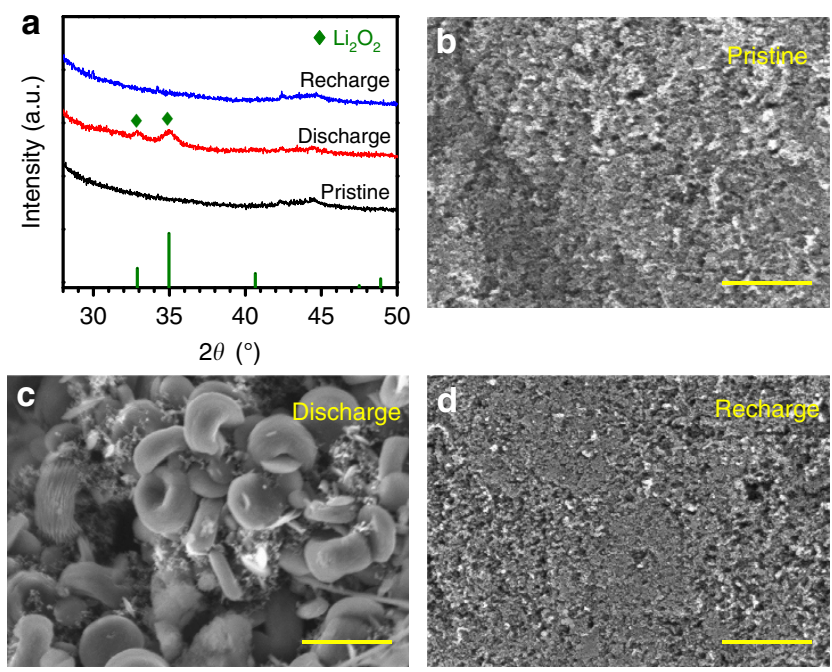

Figure 5 | Discharge products on the cathode of a $\mathrm{Li}-\mathrm{O}_{2}$ cell in the G4- $\mathbf{U H}_{\mathbf{2}} \mathbf{O}_{\mathbf{2}}$ electrolyte. (a) XRD patterns of the pristine, discharged and recharged cathodes. SEM images of $(\mathbf{b})$ the pristine cathode, (c) the discharged cathode and (d) the recharged cathode. The discharge products are identified as $\mathrm{Li}_{2} \mathrm{O}_{2}$ with typical toroid morphology. Scale bar, $2 \mu \mathrm{m}$.

titration results suggest that the charge reactions are dominated by the evolution of $\mathrm{O}_{2}$ and the consumption of $\mathrm{Li}_{2} \mathrm{O}_{2}$. Therefore, the high rechargeability of the $\mathrm{Li}-\mathrm{O}_{2}$ cell with the $\mathrm{G} 4-\mathrm{UH}_{2} \mathrm{O}_{2}$ electrolyte can be affirmed.

A comparison of the discharge-charge profiles of $\mathrm{Li}-\mathrm{O}_{2}$ cells in the electrolytes with and without $\mathrm{UH}_{2} \mathrm{O}_{2}$ in Fig. 7a,b, respectively, confirms the critical role of $\mathrm{UH}_{2} \mathrm{O}_{2}$ in ameliorating the insufficient oxygen evolution reaction catalysis ability when adopting pure $\mathrm{KB}$ carbon as the air cathode. At $500 \mathrm{~mA} \mathrm{~g}^{-1}{ }_{\mathrm{KB}}$, the $\mathrm{Li}-\mathrm{O}_{2}$ cell based on the $\mathrm{KB}$ cathode in the $\mathrm{UH}_{2} \mathrm{O}_{2}$-free electrolyte shows a charge potential as high as $\sim 4.30 \mathrm{~V}$. This high value can result in the decomposition of electrolyte and the short cycle life of the $\mathrm{Li}-\mathrm{O}_{2}$ cell. After $\sim 20$ cycles, the charge-specific capacity cannot recover to $1,000 \mathrm{mAhg}^{-1}{ }_{\mathrm{KB}}$ with a decreased Coulombic efficiency of $\sim 70 \%$. With respect to the $\mathrm{G} 4-\mathrm{UH}_{2} \mathrm{O}_{2}$ electrolyte, the cycling performance of $\mathrm{Li}-\mathrm{O}_{2}$ cell is shown in Fig. 7a,c. The electrolyte stability was evaluated through FTIR analysis (Supplementary Fig. 8). Compared with the pristine G4- $\mathrm{UH}_{2} \mathrm{O}_{2}$ electrolyte (iii), there is nearly no change in the FTIR spectra of the $\mathrm{G} 4-\mathrm{UH}_{2} \mathrm{O}_{2}$ electrolytes after discharge (iv) and charge (v), indicating no obvious decomposition of the electrolyte. After 50 cycles, the discharge profiles with plateaus at $\sim 2.68 \mathrm{~V}$ show almost no change, indicating good stability. The charge profiles present low plateaus at $\sim 3.33 \mathrm{~V}$ in the initial cycles, with a slight increment after 50 cycles. All of the 50 charge-specific capacities can achieve $1,000 \mathrm{mAh}^{-1}{ }_{\mathrm{KB}}$ with a Coulombic efficiency of $100 \%$, implying excellent reversibility. The terminal charge potentials are restricted below $\sim 4.20 \mathrm{~V}$. The improved cycling stability is attributed to this developed electrolyte additive $\mathrm{UH}_{2} \mathrm{O}_{2}$.

Considering the efficient assistance of $\mathrm{H}_{2} \mathrm{O}_{2}$ for decomposing the preloaded $\mathrm{LiOH}$ in the $\mathrm{KB}$-based cathode (Fig. 2), $\mathrm{UH}_{2} \mathrm{O}_{2}$ is also expected to solve the high charge potential for decomposing the preloaded commercial $\mathrm{Li}_{2} \mathrm{O}_{2}$. It is an essential prerequisite for constructing $\mathrm{Li}$ metal-free $\mathrm{Li}$ ion- $\mathrm{O}_{2}$ batteries ${ }^{48}$. Supplementary Fig. 9 presents the first charge profiles of $\mathrm{Li}_{-} \mathrm{O}_{2}$ cells with commercial $\mathrm{Li}_{2} \mathrm{O}_{2}$-preloaded cathodes. In the electrolyte without 
a

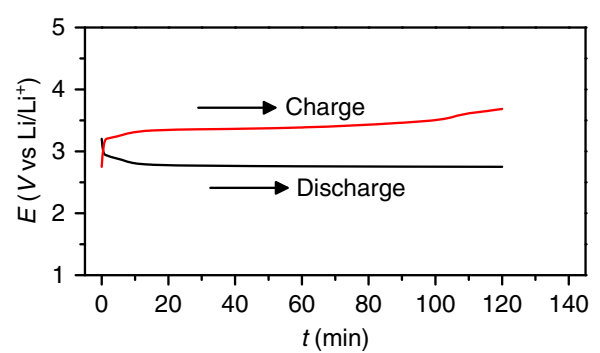

b

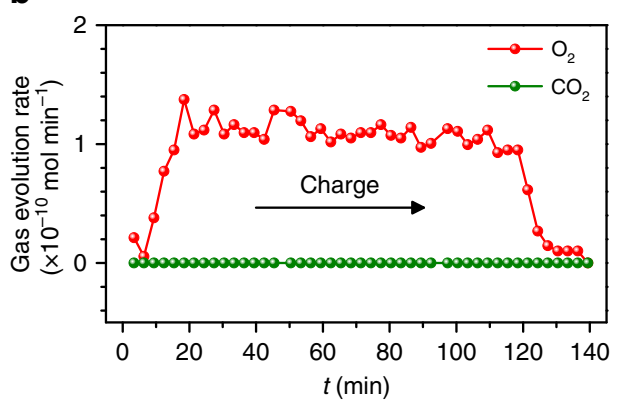

C

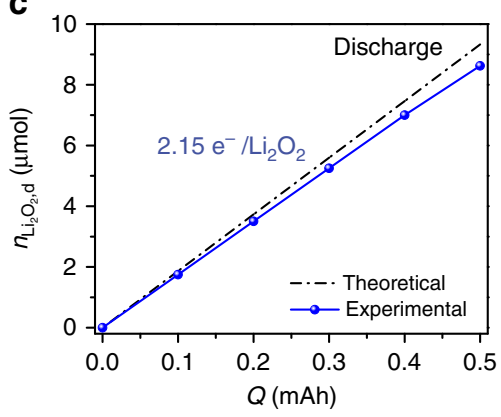

d

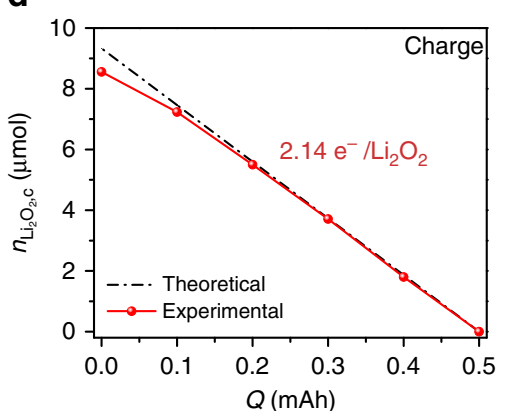

Figure 6 | Reversibility during discharge and charge processes in the $\mathbf{G} 4-\mathbf{U H}_{\mathbf{2}} \mathbf{O}_{\mathbf{2}}$ electrolyte. (a) Discharge and charge profiles of a $\mathrm{Li}-\mathrm{O}_{2}$ cell with G4- $\mathrm{UH}_{2} \mathrm{O}_{2}$ electrolyte during the in situ DEMS measurement. (b) Corresponding $\mathrm{O}_{2}$ and $\mathrm{CO}_{2}$ evolution rates during charge. (c) The quantified level of

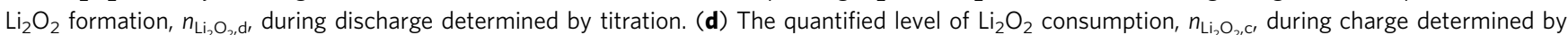
titration.
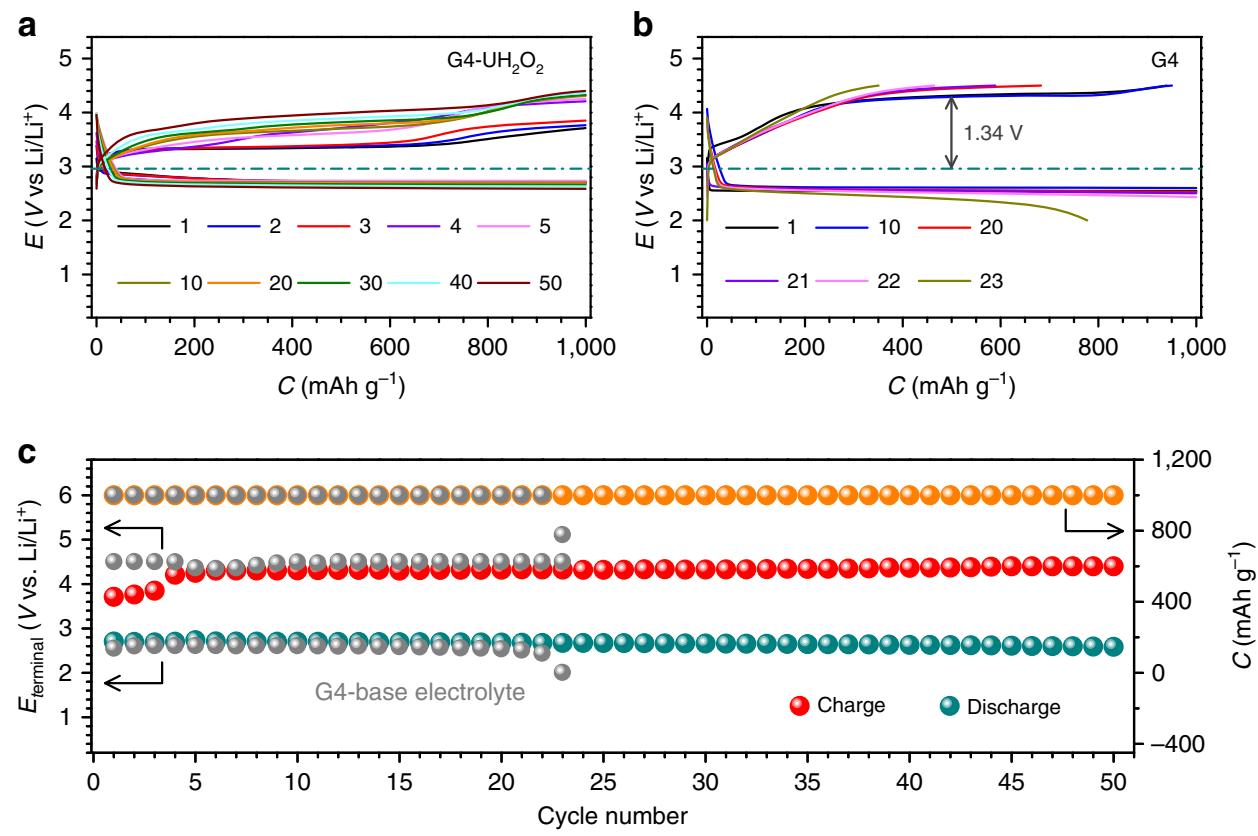

Figure 7 | Cycling performance of the $\mathbf{L i}-\mathbf{O}_{\mathbf{2}}$ cell. Selected discharge and charge profiles in (a) the $\mathrm{G} 4-\mathrm{UH}_{2} \mathrm{O}_{2}$ and (b) G4-based electrolytes. (c) The corresponding discharge and charge terminal voltages along with capacities upon cycling. Current density: $500 \mathrm{~mA} \mathrm{~g}^{-1} \mathrm{~KB}$.

any additive, a high potential peak slope at $\sim 4.32 \mathrm{~V}$, possibly arising from a thin surface coating of sparse $\mathrm{LiOH}$ or other impurities on the commercial $\mathrm{Li}_{2} \mathrm{O}_{2}$ particles, must first be overcome ${ }^{49}$. After that, the remaining part of the charge of $\mathrm{Li}_{2} \mathrm{O}_{2}$ is performed at the high potential of $\sim 3.95 \mathrm{~V}$. In the $\mathrm{G} 4-\mathrm{UH}_{2} \mathrm{O}_{2}$ electrolyte; however, the charge barrier is circumvented well and the charge potential shifts to the low value of $\sim 3.48 \mathrm{~V}$. After full charge, there is no $\mathrm{Li}_{2} \mathrm{O}_{2}$ remaining in the cathode, evidenced from the disappearance of the $\mathrm{Li}_{2} \mathrm{O}_{2}$ diffraction peaks
(Supplementary Fig. 10) and the disappearance of the $\mathrm{Li}_{2} \mathrm{O}_{2}$ particles on the cathode as observed by SEM (Supplementary Fig. 11). Accordingly, the important role of $\mathrm{UH}_{2} \mathrm{O}_{2}$ in assisting the preloaded $\mathrm{Li}_{2} \mathrm{O}_{2}$ decomposition is verified.

\section{Discussion}

For an $\mathrm{H}_{2} \mathrm{O}$-containing $\mathrm{Li}-\mathrm{O}_{2}$ battery based on $\mathrm{LiOH}$ compounds as products, we developed an accessible route of introducing 
$\mathrm{H}_{2} \mathrm{O}_{2}$ solution in the electrolyte to realize a large reduction of charge potential (from $\sim 4.16 \mathrm{~V}$ to $\sim 3.50 \mathrm{~V}$ ). The crucial role of $\mathrm{H}_{2} \mathrm{O}_{2}$ was confirmed to greatly assist the decomposition of either solid $\mathrm{LiOH}$ compounds at the cathode or liquid $\mathrm{LiOH}$ in the electrolyte. Certain factors may be implicated in improving the charge ability in the aqueous $\mathrm{Li}_{-} \mathrm{O}_{2}$ battery. Most importantly, for a non-aqueous $\mathrm{Li}-\mathrm{O}_{2}$ battery with $\mathrm{Li}_{2} \mathrm{O}_{2}$ products, we first proposed an organic $\mathrm{H}_{2} \mathrm{O}_{2}$ compound (urea hydrogen peroxide) without any $\mathrm{H}_{2} \mathrm{O}$ as the electrolyte additive to significantly decrease the charge potential (to $\sim 3.26 \mathrm{~V}$, among the best reported) and moreover to circumvent the problem of undesired $\mathrm{H}_{2} \mathrm{O}$ corrosion of the $\mathrm{Li}$ metal anode. Avoiding the damage to the $\mathrm{Li}$ metal anode ensured the enhancement of the cycling performance and the safety of the $\mathrm{Li}-\mathrm{O}_{2}$ battery. With the aid of the novel additive, the preloaded $\mathrm{Li}_{2} \mathrm{O}_{2}$ becomes easier to decompose, which aids the potential development of Li metal-free $\mathrm{Li}$ ion $\mathrm{O}_{2}$ batteries. It should be emphasized that high performance is realized at the carbon-based cathode without any additional catalysts. Although much additional work should be conducted to understand the detailed mechanisms, these results are believed to contribute to the development of pure carbon-based cathodes for $\mathrm{Li}^{-} \mathrm{O}_{2}$ batteries, enabling the benefits of superior electron conductivity, high energy density and low cost, and should trigger further efforts to exploring other possible peroxides in addition to pointing to broader design principles for electrolytes.

\section{Methods \\ Cathode preparation. KB carbon was used as the cathode material.}

Polytetrafluoroethylene (PTFE) was used as the binder. The weight ratio between $\mathrm{KB}$ and PTFE was $85: 15$. The cathodes were prepared by rolling the KB and PTFE paste in ethanol and then pressing the paste onto hydrophobic carbon papers (diameter of $7 \mathrm{~mm}$ ). The mass loading of $\mathrm{KB}$ was $\sim 1.0 \mathrm{mg} \mathrm{cm}^{-2}$. For the preparation of $\mathrm{LiOH}$-preloaded cathodes, commercial $\mathrm{LiOH}$ particles were first ballmilled in an Ar atmosphere and then mixed with $\mathrm{KB}$ to obtain the LiOH-preloaded $\mathrm{KB}$. The weight ratio between $\mathrm{LiOH}$ and $\mathrm{KB}$ was $1: 1$. For the preparation of $\mathrm{Li}_{2} \mathrm{O}_{2}$ preloaded cathodes, commercial $\mathrm{Li}_{2} \mathrm{O}_{2}$ particles and $\mathrm{KB}$ were mixed through ballmilling in an $\mathrm{Ar}$ atmosphere. The weight ratio between $\mathrm{Li}_{2} \mathrm{O}_{2}$ and $\mathrm{KB}$ was $1: 1$. Following a method similar to the $\mathrm{KB}$ cathode preparation, the $\mathrm{LiOH}$-preloaded $\mathrm{KB}$ cathodes and the $\mathrm{Li}_{2} \mathrm{O}_{2}$-preloaded $\mathrm{KB}$ cathodes were completed. Before battery assembly, all the cathodes were dried in a vacuum oven at $80^{\circ} \mathrm{C}$ for $12 \mathrm{~h}$.

Electrolyte. Tetraglyme (G4) was used as the electrolyte solvent. Before utilization, the G4 was dried by molecular sieves for 7 days. After drying in a vacuum over at $120^{\circ} \mathrm{C}$ for $24 \mathrm{~h}$, LiTFSI was used as the lithium salt. The molar concentration of the G4 electrolyte was $1 \mathrm{M}$. The $\mathrm{G} 4-\mathrm{H}_{2} \mathrm{O}$ or $\mathrm{G} 4-\mathrm{H}_{2} \mathrm{O}-\mathrm{H}_{2} \mathrm{O}_{2}$ electrolyte was prepared by adding $\mathrm{H}_{2} \mathrm{O}$ or $\mathrm{H}_{2} \mathrm{O}_{2}$ aqueous solution (30 wt\%) into the $\mathrm{G} 4$ electrolyte. The weight percentage of the $\mathrm{H}_{2} \mathrm{O}$ or $\mathrm{H}_{2} \mathrm{O}_{2}$ aqueous solution in each electrolyte was $30 \mathrm{wt} \%$. For the preparation of the $\mathrm{G} 4-\mathrm{UH}_{2} \mathrm{O}_{2}$ electrolyte, the urea hydrogen peroxide was dissolved in the dried G4 electrolyte at a weight percentage of $5 \mathrm{wt} \%$.

Cell assembly. The $\mathrm{Li}-\mathrm{O}_{2}$ pouch cell with LiSICON film to prohibit $\mathrm{H}_{2} \mathrm{O}$ crossover towards the $\mathrm{Li}$ metal anode was fabricated following the process described in previous work ${ }^{43}$. The coin-type $\mathrm{Li}-\mathrm{O}_{2}$ cell was formed in an Ar-filled glove box (<1.0 p.p.m. of $\mathrm{H}_{2} \mathrm{O}$ and 1.0 p.p.m. of $\mathrm{O}_{2}$ ) using a 2032 coin cell with 6 holes on the top. A glassy fibre filter paper was adopted as the separator. The Li metal anode was the anode. The electrolyte volume was $30 \mu \mathrm{l}$ for the LiSICON-based pouch cell and $50 \mu \mathrm{l}$ for the coin cell. The assembled cells were stored in sealed glass chambers with volume capacities of $650 \mathrm{ml}$. Before electrochemical tests, the chambers were purged with $\mathrm{O}_{2}$ (99.999\%) for at least $2 \mathrm{~h}$. The relative humidity was controlled at $\sim 75 \%$ by a saturated $\mathrm{NaCl}$ solution.

\section{Characterization and measurements. The galvanostatic discharge/charge} was conducted on a Hokuto discharging/charging system at $25^{\circ} \mathrm{C}$. The specific capacities and current densities are calculated based on the mass of $\mathrm{KB}$ in the cathodes. The in situ DEMS system used a custom-built cell connected to equipment from Perkin-Elmer (Clarus 680 and SQ 8S) ${ }^{50}$. The electrochemical impedance spectroscopy was performed on a Solartron (SI 1260) workstation at $25^{\circ} \mathrm{C}$. The frequency range was $10^{6}-10^{-2} \mathrm{~Hz}$. The amplitude was $\pm 5 \mathrm{mV}$. For ex situ XRD measurements, SEM measurement and the titration experiment of the discharged/recharged cathodes, the cells were disassembled in an Ar-filled glove box and the cathodes were extracted. The cathodes were further thoroughly washed by dimethyl ether three times to remove residual solvent and lithium salt and finally dried in a vacuum chamber connected to the glove box. XRD measurements were performed on a Bruker D8 Advance diffractometer by sealing the cathodes with a Kapton polyimide film. SEM images were taken using a JSM-6700F instrument. The titration experiments were conducted following the method of McCloskey et al. ${ }^{44}$ FTIR measurements were performed on an FT/IR-6200 spectrometer (JASCO Corp.).

Data availability. The authors declare that all the relevant data are available within the paper and its Supplementary Information file or from the corresponding author upon reasonable request.

\section{References}

1. Bruce, P. G., Freunberger, S. A., Hardwick, L. J. \& Tarascon, J.-M. Li-O 2 and Li-S batteries with high energy storage. Nat. Mater. 11, 19-29 (2012).

2. Abraham, K. M. \& Jiang, Z. A polymer electrolyte-based rechargeable lithium/oxygen battery. J. Electrochem. Soc. 143, 1-5 (1996).

3. Chang, Z.-W. et al. Recent progress on stability enhancement for cathode in rechargeable non-aqueous lithium-oxygen battery. Adv. Energy Mater. 5, 1500633 (2015).

4. Geng, D. et al. From lithium-oxygen to lithium-air batteries: challenges and opportunities. Adv. Energy Mater. 6, 1502164 (2016).

5. Manthiram, A. \& Li, L. Hybrid and aqueous lithium-air batteries. Adv. Energy Mater. 5, 1401302 (2015).

6. Wang, J. et al. Identifying reactive sites and transport limitations of oxygen reactions in aprotic lithium- $\mathrm{O}_{2}$ batteries at the stage of sudden death. Angew. Chem. Int. Ed. 55, 5201-5205 (2016).

7. Aetukuri, N. B. et al. Solvating additives drive solution-mediated electrochemistry and enhance toroid growth in non-aqueous $\mathrm{Li}_{2} \mathrm{O}_{2}$ batteries. Nat. Chem. 7, 50-56 (2015).

8. Johnson, L. et al. The role of $\mathrm{LiO}_{2}$ solubility in $\mathrm{O}_{2}$ reduction in aprotic solvents and its consequences for $\mathrm{Li}_{-} \mathrm{O}_{2}$ batteries. Nat. Chem. 6, 1091-1099 (2014).

9. $\mathrm{Xu}$, J.-J. et al. Tailoring deposition and morphology of discharge products towards high-rate and long-life lithium-oxygen batteries. Nat. Commun. 4, 2438 (2013).

10. Jung, H.-G. et al. An improved high-performance lithium-air battery. Nat. Chem. 4, 579-585 (2012)

11. Liu, B. et al. Electrochemically formed ultrafine metal oxide nanocatalysts for high-performance lithium-oxygen batteries. Nano Lett. 16, 4932-4939 (2016)

12. Wandt, J. et al. Singlet oxygen formation during the charging process of an aprotic lithium-oxygen battery. Angew. Chem. Int. Ed. 55, 6892-6895 (2016).

13. Thotiyl, M. M. O., Freunberger, S. A., Peng, Z. \& Bruce, P. G. The carbon electrode in nonaqueous $\mathrm{Li}_{-} \mathrm{O}_{2}$ Cells. J. Am. Chem. Soc. 135, 494-500 (2013).

14. Lim, H.-D. et al. Enhanced power and rechargeability of a $\mathrm{Li}^{-} \mathrm{O}_{2}$ battery based on a hierarchical-fibril CNT electrode. Adv. Mater. 25, 1348-1352 (2013).

15. Kang, S. J. et al. Deactivation of carbon electrode for elimination of carbon dioxide evolution from rechargeable lithium-oxygen cells. Nat. Commun. 5, 3937 (2014).

16. Lu, J. et al. A lithium-oxygen battery based on lithium superoxide. Nature 529, 377-382 (2016).

17. Guo, X. et al. 3D nanoporous nitrogen-doped graphene with encapsulated $\mathrm{RuO}_{2}$ nanoparticles for Li- $\mathrm{O}_{2}$ batteries. Adv. Mater. 27, 6137-6143 (2015).

18. Jeong, Y. S. et al. Study on the catalytic activity of noble metal nanoparticles on reduced graphene oxide for oxygen evolution reactions in lithium-air batteries. Nano Lett. 15, 4261-4268 (2015).

19. Oh, S. H. et al. Synthesis of a metallic mesoporous pyrochlore as a catalyst for lithium- $\mathrm{O}_{2}$ batteries. Nat. Chem. 4, 1004-1010 (2012).

20. Lu, J. et al. A nanostructured cathode architecture for low charge overpotential in lithium-oxygen batteries. Nat. Commun. 4, 2383 (2013).

21. Oh, D. et al. Biologically enhanced cathode design for improved capacity and cycle life for lithium-oxygen batteries. Nat. Commun. 4, 2756 (2013).

22. Peng, Z., Freunberger, S. A., Chen, Y. \& Bruce, P. G. A reversible and higher-rate $\mathrm{Li}^{-} \mathrm{O}_{2}$ battery. Science 337, 563-566 (2012).

23. Lu, Y.-C. et al. Platinum-gold nanoparticles: a highly active bifunctional electrocatalyst for rechargeable lithium-air batteries. J. Am. Chem. Soc. 132, 12170-12171 (2010).

24. Tan, P. et al. A nano-structured $\mathrm{RuO}_{2} / \mathrm{NiO}$ cathode enables the operation of non-aqueous lithium-air batteries in ambient air. Energy Environ. Sci. 9, 1783-1793 (2016).

25. Bhattacharya, P. et al. Dendrimer-encapsulated ruthenium oxide nanoparticles as catalysts in lithium-oxygen batteries. Adv. Funct. Mater. 24, 7510-7519 (2014).

26. Sun, B., Chen, S., Liu, H. \& Wang, G. Mesoporous carbon nanocube architecture for high-performance lithium-oxygen batteries. Adv. Funct. Mater. 25, 4436-4444 (2015).

27. Cui, Z., Li, L., Manthiram, A. \& Goodenough, J. B. Enhanced cycling stability of hybrid Li-air batteries enabled by ordered Pd3Fe intermetallic electrocatalyst. J. Am. Chem. Soc. 137, 7278-7281 (2015). 
28. Tang, J. et al. Cage-type highly graphitic porous carbon- $\mathrm{Co}_{3} \mathrm{O}_{4}$ polyhedron as the cathode of lithium-oxygen batteries. ACS Appl. Mater. Interfaces 8, 2796-2804 (2016).

29. Ottakam Thotiyl, M. M. et al. A stable cathode for the aprotic $\mathrm{Li}^{-\mathrm{O}_{2}}$ battery. Nat. Mater. 12, 1050-1056 (2013).

30. Kundu, D., Black, R., Berg, E. J. \& Nazar, L. F. A highly active nanostructured metallic oxide cathode for aprotic $\mathrm{Li}_{2} \mathrm{O}_{2}$ batteries. Energy Environ. Sci. 8, 1292-1298 (2015)

31. Krishnamurthy, D., Hansen, H. A. \& Viswanathan, V. Universality in nonaqueous alkali oxygen reduction on metal surfaces: implications for $\mathrm{Li}-\mathrm{O}_{2}$ and $\mathrm{Na}-\mathrm{O}_{2}$ batteries. ACS Energy Lett. 1, 162-168 (2016).

32. McCloskey, B. D. \& Addison, D. A viewpoint on heterogeneous electrocatalysis and redox mediation in nonaqueous $\mathrm{Li}^{-} \mathrm{O}_{2}$ batteries. ACS Catal. 7, 772-778 (2017).

33. Li, F. et al. The water catalysis at oxygen cathodes of lithium-oxygen cells. Nat. Commun. 6, 7843 (2015).

34. Wu, S. et al. Low charge overpotentials in lithium-oxygen batteries based on tetraglyme electrolytes with a limited amount of water. Chem. Commun. 51, 16860-16863 (2015)

35. Wu, S. et al. A synergistic system for lithium-oxygen batteries in humid atmosphere integrating a composite cathode and a hydrophobic ionic liquid-based electrolyte. Adv. Funct. Mater. 26, 3291-3298 (2016).

36. Meini, S. et al. The effect of water on the discharge capacity of a non-catalyzed carbon cathode for $\mathrm{Li}_{-} \mathrm{O}_{2}$ batteries. Electrochem. Solid State Lett. 15, A45-A48 (2012).

37. Schwenke, K. U. et al. The influence of water and protons on $\mathrm{Li}_{2} \mathrm{O}_{2}$ crystal growth in aprotic Li-O ${ }_{2}$ cells. J. Electrochem. Soc. 162, A573-A584 (2015).

38. Liu, T. et al. Cycling $\mathrm{Li}^{-} \mathrm{O}_{2}$ batteries via $\mathrm{LiOH}$ formation and decomposition. Science 350, 530-533 (2015).

39. Shen, Y., Zhang, W., Chou, S. L. \& Dou, S. X. Comment on 'Cycling Li-O batteries via LiOH formation and decomposition'. Science 352, 667 (2016).

40. Viswanathan, V. et al. Comment on 'Cycling $\mathrm{Li}-\mathrm{O}_{2}$ batteries via $\mathrm{LiOH}$ formation and decomposition'. Science 352, 667 (2016).

41. Burke, C. M. et al. Implications of $4 \mathrm{e}^{-}$oxygen reduction via iodide redox mediation in $\mathrm{Li}_{-} \mathrm{O}_{2}$ batteries. ACS Energy Lett. 1, 747-756 (2016).

42. Burke, C. M. et al. Implications of $4 \mathrm{e}^{-}$oxygen reduction viaiodide redox mediation in $\mathrm{Li}_{-} \mathrm{O}_{2}$ batteries. ACS Energy Lett. 1, 747-756 (2016).

43. Wang, Y. \& Zhou, H. A lithium-air battery with a potential to continuously reduce $\mathrm{O}_{2}$ from air for delivering energy. J. Power Sources 195, 358-361 (2010).

44. McCloskey, B. D. et al. Combining accurate $\mathrm{O}_{2}$ and $\mathrm{Li}_{2} \mathrm{O}_{2}$ assays to separate discharge and charge stability limitations in nonaqueous $\mathrm{Li}-\mathrm{O}_{2}$ batteries. J. Phys. Chem. Lett. 4, 2989-2993 (2013).

45. Kim, H., Ding, Y. \& Kohl, P. A. LiSICON-ionic liquid electrolyte for lithium ion battery. J. Power Sources 198, 281-286 (2012).

46. Kanno, R. et al. A self-assembled breathing interface for all-solid-state ceramic lithium batteries. Electrochem. Solid State Lett. 7, A455-A458 (2004).
47. Lesch, V. et al. Atomistic insights into deep eutectic electrolytes: the influence of urea on the electrolyte salt LiTFSI in view of electrochemical applications. Phys. Chem. Chem. Phys. 18, 28403-28408 (2016).

48. Wu, S. et al. A long-life lithium ion oxygen battery based on commercial silicon particles as the anode. Energy Environ. Sci. 9, 3262-3271 (2016).

49. Meini, S. et al. Rechargeability of Li-air cathodes pre-filled with discharge products using an ether-based electrolyte solution: implications for cycle-life of Li-air cells. Phys. Chem. Chem. Phys. 15, 11478-11493 (2013).

50. Yang, S. X., He, P. \& Zhou, H. S. Exploring the electrochemical reaction mechanism of carbonate oxidation in Li-air/ $\mathrm{CO}_{2}$ battery through tracing missing oxygen. Energy Environ. Sci. 9, 1650-1654 (2016).

\section{Acknowledgements}

The financial support from the ALCA of Japan project, the National Basic Research Program of China (2014CB932300) and the NSF of China (21373111) are acknowledged

\section{Author contributions}

S.W. designed and performed the experiments. Y.Q. conducted the SEM and FTIR studies. S.Y. performed the in situ DEMS test. All the authors contributed to the discussion. S.W. wrote the manuscript and H.Z. supervised the work.

\section{Additional information}

Supplementary Information accompanies this paper at http://www.nature.com/ naturecommunications

Competing interests: The authors declare no competing financial interests.

Reprints and permission information is available online at http://npg.nature.com/ reprintsandpermissions/

How to cite this article: $\mathrm{Wu}, \mathrm{S}$. et al. Organic hydrogen peroxide-driven low charge potentials for high-performance lithium-oxygen batteries with carbon cathodes. Nat. Commun. 8, 15607 doi: 10.1038/ncomms15607 (2017).

Publisher's note: Springer Nature remains neutral with regard to jurisdictional claims in published maps and institutional affiliations.

(c) (i) This work is licensed under a Creative Commons Attribution 4.0 International License. The images or other third party material in this article are included in the article's Creative Commons license, unless indicated otherwise in the credit line; if the material is not included under the Creative Commons license, users will need to obtain permission from the license holder to reproduce the material. To view a copy of this license, visit http://creativecommons.org/licenses/by/4.0/

(C) The Author(s) 2017 